\title{
Rumblings grow about Parkfield in wake of first earthquake prediction
}

Pasadena. Seismologists and California officials last week pronounced the first official short-term earthquake prediction a success despite the fact that the event did not occur. But the activity has renewed criticism of a \$19-million project in a remote region of central California.

The prediction, triggered by a magnitude 4.7 earthquake last week in Parkfield (population 34), warned of a 37 per cent chance of a magnitude 6 earthquake for a 72-hour period beginning on Monday, 19 October. This past Sunday evening, after the Level A alert was withdrawn, a Level B alert was issued when tremblors of magnitude 3.4 and 3.9 struck the area. That means a 10 per cent chance of a magnitude 6 earthquake in the next 72 hours.

Parkfield, located on the San Andreas fault midway between Los Angeles and San Francisco, is the subject of intense study because of a remarkably regular series of magnitude 6 earthquakes every 22 years or so beginning in 1857. In 1985, the United States Geological Survey (USGS) launched the Parkfield Prediction Experiment after declaring that there was a 95 per cent chance of another magnitude 6 earthquake by January 1993.

The project has saturated the area around Parkfield with equipment to measure the earthquake and a variety of possible precursors, including changes in the Earth's magnetic field and in the water levels of local wells. But the expected earthquake has so far failed to occur, and the controversial experiment is criticized for having a serious statistical flaw and for diverting money and resources that might be better used in areas likely to be struck by far larger and more damaging earthquakes.

The statistical criticism comes from Mark Matthews, a statistician at the Massachusetts Institute of Technology, who says that the 1985 forecast was made by omitting an event in 1934, which inconveniently occurred only 12 years after the previous earthquake and 32 years before the next one. Although the authors of the 1985 study maintained that they had valid physical reasons for believing that the 1934 earthquake was uncharacteristic, Matthews maintains that these justifications are "simplistic and wishful" and "not really scientifically defensible".
Matthews' own calculations, which include the 1934 earthquake, indicate that the next event after 1966 would have been expected in 1982, \pm 16.6 years. In addition, his calculations show that the probability of the magnitude 6 earthquake happening between 1983 and 1993 (the original forecast interval) is only 40 per cent.

\section{$\$ 2$ million a year to operate.}

One problem with the experiment is that its short-term prediction was based on only a 37 per cent chance of an earthquake. Some worry that too many false alarms will cause the public to disregard future warnings. Michael, however, points out that short-term earthquake predictions with higher probabilities are as yet impossible. As a result, seismologists and state officials long ago decided to err on the side of providing the public with more rather than less information in the belief that the public would be outraged if seismologists failed to announce a prediction that proved correct.

Even critics agree that the experiment has improved communications between scientists and government planners. State officials regard even a failed earthquake prediction in a remote area as valuable preparation for larger earthquakes in both northern and southern California. In response to the Parkfield alert, for example, seven California counties within

USGS geophysicist Andy Michael agrees that the experiment may have been "oversold" but argues that Parkfield still gives seismologists their best chance of observing a significant earthquake within a relatively short time. He says that the experiment should continue beyond January whether or not the predicted earthquake occurs. Michael says that a similar experiment elsewhere would be expensive and that seven years of accumulated baseline data at Parkfield is irreplaceable. An external review board is scheduled to issue a report in December on the future of the project, which costs

100 miles of the epicentre activated their emergency-operations centres, and local police, fire and medical-services agencies took such steps as alerting personnel, reviewing emergency plans, making sure emergency generators were running and moving emergency vehicles out of doors.

The public also took precautions by buying more bottled water, flashlights and batteries. It seems that, to most Californians, the prediction was simply another reminder of the inevitability of a Big One.

Robert Finn

\section{Groups sue to end fetal tissue ban}

Washington. Following the latest failure to overturn the US ban on research using fetal tissue, five disease and research groups took matters into their own hands last week and sued the federal government.

The groups, which include the Association of American Medical Colleges, the Association of American Universities and three disease groups, claim that the US Department of Health and Human Services violated the Administrative Procedures Act when, in 1989, it made permanent a temporary ban on the research without following the law on proper public notice. Congress has tried several times to overturn the ban but has failed to muster the two-thirds majority needed to overturn a presidential veto.

But events may overtake the lawsuit. Congress has promised to try to repeal the ban early next year and supporters believe that they have the votes to win. A Democrat in the White House would render the whole issue moot because overturning the ban is part of the party's platform.

Christopher Anderson 